\title{
BIOCHEMICAL CHANGES DURING THE DEVELOPMENT OF RESPIRATORY ACTIVITY IN ESCHERICHIA COLI
}

\section{CHANGES IN ENZYME ACTIVITIES}

\author{
YOSHIO TAKAHASHI ${ }^{1}$ AND SEIICHI HINO \\ Botanical Institute, Faculty of Science, Hiroshima University, Hiroshima
}

(Received July 4, 1968)

\begin{abstract}
Cell-free extracts were prepared from four types of Escherichia coli cells; cells grown aerobically with glucose, cells grown aerobically without glucose, cells grown anaerobically with glucose, and cells obtained after aeration of the anaerobically grown cells. Examination of the activities of about 20 enzymes in these extracts showed that glucose and oxygen in growth environment generally do not significantly influence the level of enzymes in fermentative pathways. The presence of oxygen during the growth increased the level of formate dehydrogenase, NADH oxidase system, and several enzymes in the tricarboxylic acid cycle, particularly isocitrate dehydrogenase and succinyl-CoA synthetase. The presence of glucose during the growth repressed the level of several enzymes in the glyoxylate cycle, particularly isocitrate lyase and citrate synthase. When thick suspensions of the cells grown anaerobically with glucose were aerated in a glucose-free incubation mixture for $4 \mathrm{hr}$, initial low activities of about 10 enzymes increased to the level of cells grown aerobically in the absence of glucose, without accompanying significant cell multiplication.
\end{abstract}

In our previous papers $(1,2)$, it was disclosed that low respiratory activity of anaerobically grown cells of Escherichia coli $\mathrm{K}-12$ increased to the level of aerobically grown cells by aeration under conditions that preclude cell division. It was also shown that the change of cellular permeability is one of the causes of this development of respiratory activity. In addition, several experimental results gave an indication that synthesis of respiratory enzymes is also responsible for the development of respiration. These experimental results are: (a) The development of respiration occurred only in the presence of amino acids, (b) the development was inhibited by inhibitors of protein synthesis, (c) respiratory activity of cell-free extracts was increased by aeration of the cells, and (d) nondialyzable substance or substances that

1 Present address: Department of Biology, Fukuoka University of Education, Munakata, Fukuoka. 
are responsible for respiration were formed during the development of respiration.

To examine what kind of enzymes are formed, extracts prepared from the cells before and after aeration were tested for the activity of about 20 enzymes, including those that belong to the member of tricarboxylic acid cycle and glyoxylate cycle. Since glucose was found to be toxic for the development of respiration ( 1 ), activities of these enzymes were also examined by using extracts from the cells grown aerobically in media, with or without glucose added. The results are described in the present paper.

\section{MATERIALS AND METHODS}

Organism, culture media, and growth conditions. The organism used in this study was Escherichia coli K-12 (Cavalli's Hfr strain). The media, cultural conditions, and procedures for harvesting and washing the cells were essentially the same as described in detail in the previous paper (1). Aerobic cultures were grown by shaking in a nutrient broth either with or without the addition of $1 \%$ glucose. Anaerobic cultures were grown in bottles filled to the neck with the nutrient broth containing $1 \%$ glucose. Incubation was made for $18 \mathrm{hr}$ at $30^{\circ}$. Although glucose is toxic to the development of respiration in $E$. coli, glucose-containing media were used for anaerobic cultures, since elimination of glucose from the media resulted in poor yield of the cells.

Aeration of anaerobically grown cells. Anaerobically grown cells were washed and suspended in a phosphate buffer ( $\mathrm{pH} 7.2,0.02 \mathrm{M}$ ), containing $2 \%$ casamino acids (Nissan) and $2 \%$ beef extract (Kyokuto). The cell suspension was made sufficiently concentrated (about $5 \times 10^{10}$ cells per $\mathrm{ml}$ ) to prevent cell multiplication and shaken in air for $4 \mathrm{hr}$ at $30^{\circ}$.

General procedures for the assay of enzyme activity. Cell-free extracts were prepared by sonic treatment as described previously (2). The assay method for all enzymes was either essentially the same as described in the reference literature or with slight modification of the original method. Most of the enzyme activities were measured at least in triplicate and the values presented are the mean of different measurements. All activities are expressed as $\mu$ moles of the substrate consumed or of the product formed per min per $\mathrm{mg}$ nitrogen of the extracts. The nitrogen content of the cell-free extracts was determined indirectly using a standard curve drawn between the amount of protein and nitrogen per $\mathrm{ml}$ of the extracts, assayed by the biuret and micro-Kjeldahl method, respectively.

Spectrophotometric measurements were carried out with a Hitachi spectrophotometer model EPU-2A in cuvettes with a $1 \mathrm{~cm}$ light path.

Assay of the enzymes listed in Table 1. Measurements of the enzyme activities listed in Table 1 were carried out as follows. Complete reaction mixtures contained the substrate, buffer, and other additions in final concentrations as shown in columns (b) and (c) of the table, in a total volume of $3 \mathrm{ml}$. 


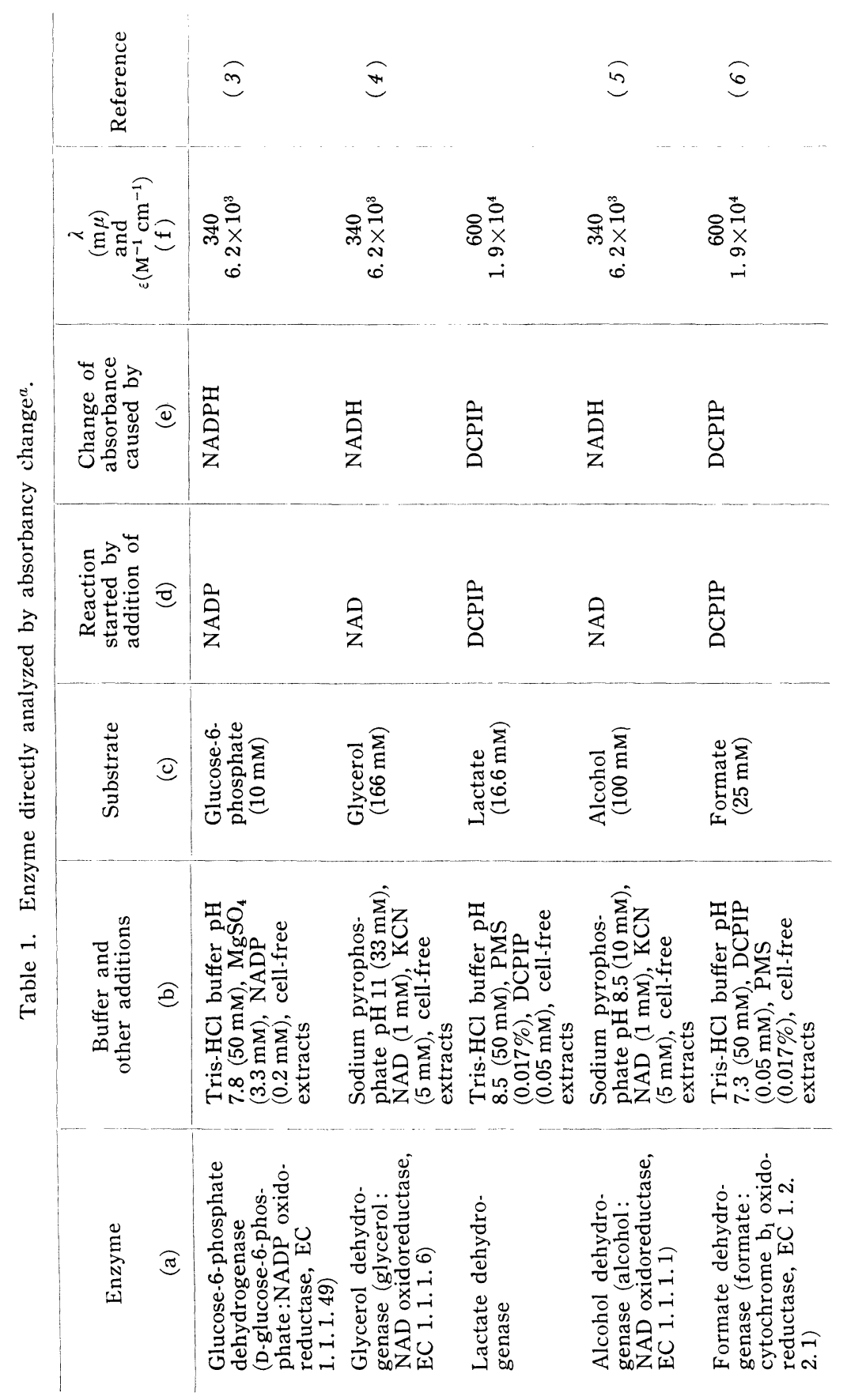


Table 1. (continued 1)

\begin{tabular}{|c|c|c|c|c|c|c|}
\hline $\begin{array}{c}\text { Enzyme } \\
\text { (a) }\end{array}$ & $\begin{array}{l}\text { Buffer and } \\
\text { other additions } \\
\text { (b) }\end{array}$ & $\begin{array}{c}\text { Substrate } \\
\text { (c) }\end{array}$ & $\begin{array}{l}\text { Reaction } \\
\text { started by } \\
\text { addition of } \\
\text { (d) }\end{array}$ & $\begin{array}{l}\text { Change of } \\
\text { absorbance } \\
\text { caused by } \\
\text { (e) }\end{array}$ & $\begin{array}{c}\lambda \\
(\mathrm{m} \mu) \\
\text { and } \\
\varepsilon\left(\mathrm{M}^{-1} \mathrm{~cm}^{-1}\right) \\
(\mathbf{f})\end{array}$ & Reference \\
\hline $\begin{array}{l}\text { Isocitrate lyase } \\
\text { (Ls-isocitrate glyoxy- } \\
\text { late-lyase, EC } \\
\text { 4.1.3.1) }\end{array}$ & $\begin{array}{l}\text { Potassium phosphate } \\
\text { buffer } \mathrm{pH} 7.2(60 \mathrm{mM}), \\
\mathrm{MgSSO}_{4}(5 \mathrm{mM}), \\
\text { phenylhydrazine } \\
(3 \mathrm{mM}), \text { cysteine } \\
(2 \mathrm{mM}), \text { cell-free } \\
\text { extracts }\end{array}$ & $\begin{array}{c}\text { Isocitrate } \\
(15 \mathrm{mM})\end{array}$ & Isocitrate & $\begin{array}{l}\text { Glyoxylate- } \\
\text { phenyl- } \\
\text { hydrazine }\end{array}$ & $\begin{array}{c}324 \\
1.7 \times 10^{4}\end{array}$ & (7) \\
\hline $\begin{array}{l}\text { Isocitrate dehydro- } \\
\text { genase (LS-isocitrate: } \\
\text { NADP oxidoreductase } \\
\text { (decarboxylating), } \\
\text { EC 1.1.1.42) }\end{array}$ & $\begin{array}{l}\text { Potassium phosphate } \\
\text { buffer pH } 7.2(20 \mathrm{mM}) \text {, } \\
\text { MgSO }_{4}(5 \mathrm{mM}), \\
\text { NADP }(0.2 \mathrm{mM}) \text {, } \\
\text { cell-free extracts }\end{array}$ & $\begin{array}{c}\text { Isocitrate } \\
(10 \mathrm{mM})\end{array}$ & NADP & NADPH & $\begin{array}{c}340 \\
6.2 \times 10^{3}\end{array}$ & ( 8 ) \\
\hline $\begin{array}{l}\text { Aconitate hydratase } \\
\text { (citrate (isocitrate) } \\
\text { hydro-lyase, EC 4.2. } \\
\text { 1.3) }\end{array}$ & $\begin{array}{l}\text { Potassium phosphate } \\
\text { buffer } \mathrm{pH} 7.2(60 \mathrm{mM}) \text {, } \\
\mathrm{MgSO}_{4}(5 \mathrm{mM}) \text {, cell- } \\
\text { free extracts }\end{array}$ & $\begin{array}{c}\text { Isocitrate } \\
(15 \mathrm{mM})\end{array}$ & Isocitrate & Aconitate & $\begin{array}{c}240 \\
2.4 \times 10^{3}\end{array}$ & (9) \\
\hline $\begin{array}{l}\text { Succinate dehydro- } \\
\text { genase (succinate: } \\
\text { (acceptor) oxido- } \\
\text { reductase, EC } 1.3 \text {. } \\
99.1 \text { ) }\end{array}$ & $\begin{array}{l}\text { Potassium phosphate } \\
\text { buffer } \mathrm{pH} 7.2(40 \mathrm{mM}), \\
\mathrm{MgSO}_{4}(5 \mathrm{mM}), \mathrm{PMS} \\
(0.017 \%), \mathrm{DCPIP} \\
(0.033 \mathrm{mM}) \text {, cell-free } \\
\text { extracts }\end{array}$ & $\begin{array}{l}\text { Succinate } \\
(33 \mathrm{mM})\end{array}$ & DCPIP & DCPIP & $\begin{array}{c}600 \\
1.9 \times 10^{4}\end{array}$ & (10) \\
\hline $\begin{array}{l}\text { Fumarate hydratase } \\
\text { (L-malate hydro-lyase, } \\
\text { EC } 4.2 .1 .2 \text { ) }\end{array}$ & $\begin{array}{l}\text { Potassium phosphate } \\
\text { buffer pH } 7.2(20 \mathrm{mM}) \\
\mathrm{MgSO}_{4}(5 \mathrm{mM}) \text {, cell- } \\
\text { free extracts }\end{array}$ & $\begin{array}{l}\text { Malate } \\
(20 \mathrm{mM})\end{array}$ & $\begin{array}{l}\text { Cell-free } \\
\text { extracts }\end{array}$ & Fumarate & $\begin{array}{c}240 \\
2.4 \times 10^{3}\end{array}$ & (9) \\
\hline
\end{tabular}




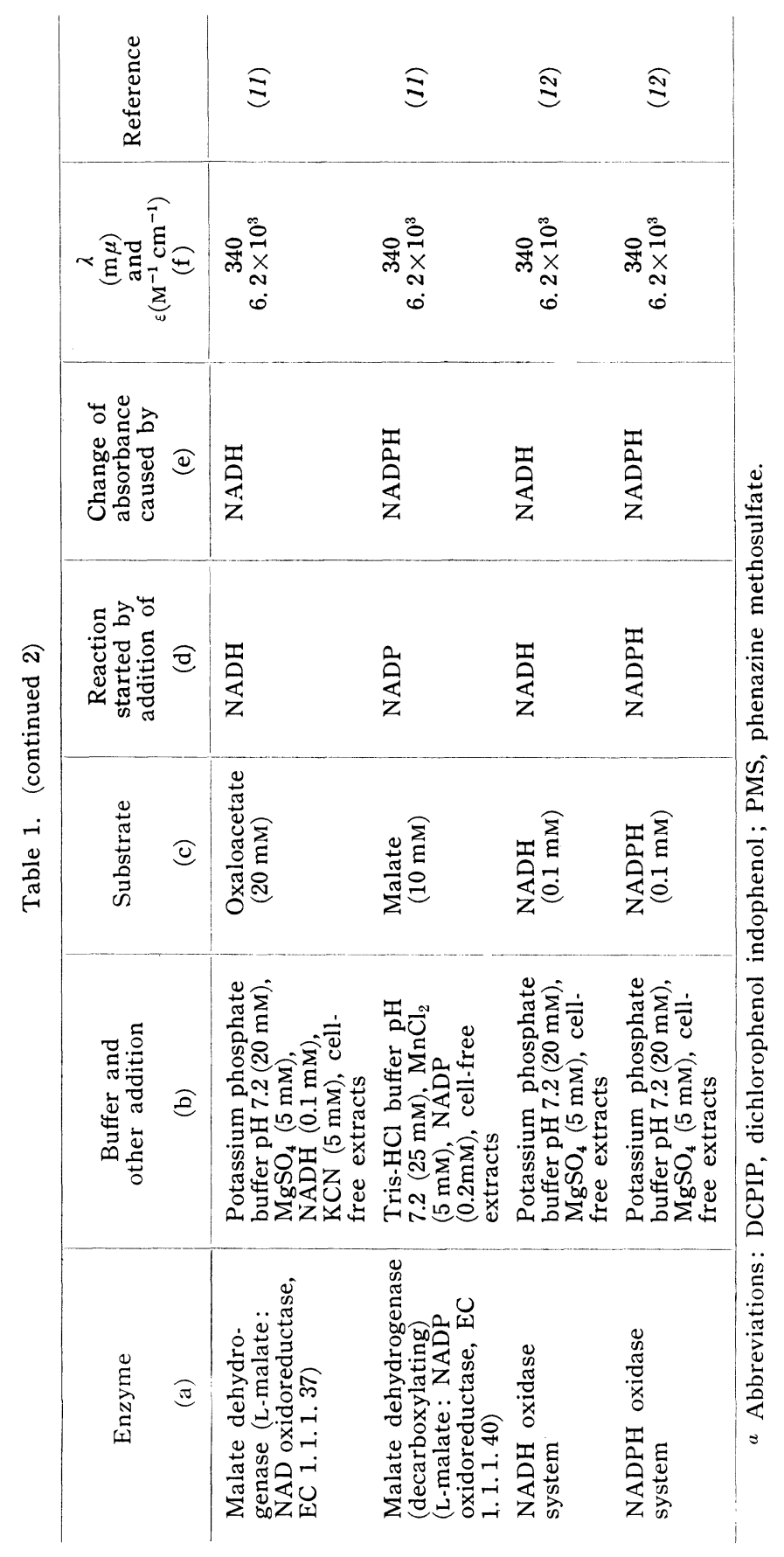


Reactions were started in spectrophotometer cuvettes by the addition of coenzymes, dyes, substrates, or extracts as shown in column (d), using control cuvettes from which these additions were eliminated. Reaction mixtures for the assay of alcohol, glycerol, and NAD-malate dehydrogenases contained $\mathrm{KCN}$, since otherwise $\mathrm{NADH}$ was oxidized by $\mathrm{NADH}$ oxidase in cell-free extracts. Formate dehydrogenase was tested in a Thunberg tube-type cuvette as described by ITAGAKI et al. (6), because this enzyme is inactivated by oxygen.

Reactions were followed by recording the change in optical densities caused by the components listed in column (e), at appropriate wavelength as shown in column (f). After running the reaction for 3 to $5 \mathrm{~min}$ at room temperature $\left(20^{\circ}\right.$ to $\left.25^{\circ}\right)$, the activities of enzymes were calculated from the highest rate of the reaction.

Assay of the enzymes not listed in Table 1. Pyruvate decarboxylase (2-oxo-acid carboxy-lyase, EC 4.1.1.1) and oxaloacetate decarboxylase (oxaloacetate carboxy-lyase, EC 4.1.1.3) were determined manometrically by measuring the amount of $\mathrm{CO}_{2}$ evolved in $\mathrm{N}_{2}$ atmosphere during the first $5 \mathrm{~min}$ after the addition of substrate at $30^{\circ}(13)$. The main chamber of the Warburg vessel contained $30 \mathrm{mM}$ potassium phosphate buffer $(\mathrm{pH} 7.2), 2.5 \mathrm{mM} \mathrm{MgSO}_{4}$, $0.5 \mathrm{mM}$ NAD, $0.5 \mathrm{~mm}$ thiamine pyrophosphate, and cell-free extracts in a total volume of $1.8 \mathrm{ml}$. To one side arm was added $0.2 \mathrm{ml}$ of $3 \mathrm{~N} \mathrm{H}_{2} \mathrm{SO}_{4}$ and to the other $0.2 \mathrm{ml}$ of $0.2 \mathrm{M}$ sodium pyruvate or sodium oxaloacetate. Vessels were also set up to determine bound and endogenous $\mathrm{CO}_{2}$ production.

Acetate kinase (ATP: acetate phosphotransferase, EC 2.7.2.1) was estimated at $30^{\circ}$ by a method similar to that of ROSE (14). The components in the system were $100 \mathrm{mM}$ Tris- $\mathrm{HCl}$ buffer ( $\mathrm{pH} 7.7$ ), $3.2 \mathrm{~m} \mathrm{M} \mathrm{MgCl}_{2}, 480 \mathrm{mM}$ hydroxylamine ( $\mathrm{pH} 7.0), 10 \mathrm{mM} \mathrm{ATP}, 77.5 \mathrm{mM}$ acetate, and cell-free extracts in a final volume of $1 \mathrm{ml}$. Acetyl phosphate formed during 2 min was estimated by the hydroxamic acid method of LIPMANN and TuTTLE (15). Succinic anhydride was used to prepare a standard hydroxamic acid solution.

Phosphate acetyltransferase (acetyl-CoA : orthophosphate acetyltransferase, EC 2.3.1.8) activity was measured by the arsenolysis method of STADTMAN et al. (16). The system consisted of $10 \mathrm{mM}$ Tris- $\mathrm{HCl}$ buffer ( $\mathrm{pH} 7.2), 50 \mathrm{mu}$ arsenate, $10 \mathrm{~m} . \mathrm{m}$ cysteine, $0.2 \mathrm{~m}: \mathrm{I}$ CoA, $6 \mathrm{~m}$. dilithium acetyl phosphate, and cell-free extracts in a total volume of $1 \mathrm{ml}$. Residual acetyl phosphate after incubation for $2 \mathrm{~min}$ at $30^{\circ}$ was determined by the hydroxamic acid procedure (15).

Estimation of the activity of citrate synthase (citrate oxaloacetate-lyase, EC 4.1.3.7) was based on the ability of to synthesize citrate from acetyl phosphate and oxaloacetate (17). It was confirmed that extracts used for this assay contained sufficiently active phosphate acetyltransferase, so that conversion of acetyl phosphate to acetyl-CoA is not the rate-limiting step in this reaction. The assay system consisted of $30 \mathrm{mM}$ potassium phosphate buffer ( $\mathrm{pH} 7.2$ ), $5 \mathrm{mM} \mathrm{MgSO}_{4}, 0.2 \mathrm{mM} \mathrm{CoA}, 10 \mathrm{mM}$ cysteine, $22.5 \mathrm{mM}$ oxalo- 
acetate, $10 \mathrm{mM}$ dilithium acetyl phosphate, and cell-free extracts in a final volume of $1 \mathrm{ml}$. Activity was calculated from the amount of citrate synthesized during the first $2 \mathrm{~min}$ after the addition of the extracts at $30^{\circ}$. Before the estimation of citrate, interfering substances such as $\beta$-keto acids were removed by autoclaving $(18)$ from the reaction mixture.

Succinyl-CoA synthetase (succinate: CoA ligase (ADP), EC 6.2.1.5) was measured by the method of KAUfMAN (19). The reaction mixture contained $50 \mathrm{mM}$ Tris-HCl buffer ( $\mathrm{pH} 7.4), 480 \mathrm{mM}$ hydroxylamine $(\mathrm{pH} \mathrm{7.0)}, 10 \mathrm{mM}$ reduced glutathione, $10 \mathrm{mM}$ ATP, $5 \mathrm{mM} \mathrm{MgCl}_{2}, 50 \mathrm{mM}$ succinate, $0.2 \mathrm{mM} \mathrm{CoA}$, and cell-free extracts in a final volume of $1 \mathrm{ml}$. The mixture was incubated at $30^{\circ}$ for $20 \mathrm{~min}$. Succinohydroxamic acid formed was assayed by the same method as for acetyl phosphate.

Chemicals. Coenzyme A, dilithium acetyl phosph -te, and glutathione (reduced) were obtained from the C.F. Boehringer and Soehne GmbH; ATP, $\mathrm{NAD}, \mathrm{NADH}, \mathrm{NADP}, \mathrm{NADPH}$, phenazine methosulfate, and $\mathrm{D}, \mathrm{L}$-isocitric acid lactone were from the Sigma Chemical Co.; 2,6-dichlorophenol indophenol and thiamine pyrophosphate were from Wako Pure Chemical Industries Co.; glucose-6-phosphate was from Katayama Chemical Industries Co.; glyoxylic acid was from Ishizu Pharmaceutical Co.; D, L-Isocitric acid lactone was converted into the free acid by the method of DEUTSCH and PHILlips (20).

\section{RESULTS}

In Table 2 is listed the activity of individual enzymes in a crude extract from four types of cells; cells grown aerobically in glucose-free media, cells grown aerobically in glucose-containing media, cells grown anaerobically in glucose-containing media and cells obtained after aeration of such anaerobically grown cells in virtual absence of cell multiplication.

These four types of cells did not show a significant difference in the activities of glucose-6-phosphate, glycerol, and lactate dehydrogenases, though aerobically grown cells in glucose-containing media were less active in lactate dehydrogenase. The activity of alcohol dehydrogenase in aerobically grown cells in glucose-free media appears to be lower than in other types of cells, but the activity of this enzyme was variable in different determinations owing to its low level, so that definite conclusion is to be deferred.

The activity of formate dehydrogenase in aerobically grown cells was about thirty times that of anaerobically grown cells. Aeration of the anaerobic cells resulted in marked increase in the activity, but the activity did not reach the level of aerobically grown cells. The cellular activity of this enzyme was little influenced by the presence of glucose in culture media.

Pyruvate decarboxylase was slightly more active in cells grown aerobically with glucose than the other types of cells, while acetate kinase and phosphate acetyltransferase were slightly less active in cells grown aerobically without glucose. The latter two enzymes were the most active of all the 
Table 2. Effect of growth conditions and effect of aeration of anaerobic cells on enzyme activities in E. colia.

\begin{tabular}{|c|c|c|c|c|c|c|c|}
\hline \multirow[b]{2}{*}{ Enzyme } & \multicolumn{4}{|c|}{ Enzyme activity ( $\mu$ moles $/ \mathrm{min} / \mathrm{mg} \mathrm{N}$ ) in extracts from } & \multicolumn{3}{|c|}{ Ratio of enzyme activity } \\
\hline & $\begin{array}{l}\text { Aerobic } \\
\text { cells grown } \\
\text { without } \\
\text { glucose } \\
\text { (a) }\end{array}$ & $\begin{array}{l}\text { Aerobic } \\
\text { cells grown } \\
\text { with } \\
\text { glucose } \\
\text { (b) }\end{array}$ & $\begin{array}{l}\text { Anaerobic } \\
\text { cells grown } \\
\text { with } \\
\text { glucose } \\
\text { (c) }\end{array}$ & $\begin{array}{l}\text { Cells after } \\
\text { aeration of } \\
\text { anaerobic } \\
\text { cells }{ }^{b} \\
\text { (d) }\end{array}$ & $\begin{array}{l}\frac{(b)}{(c)} \\
(e)\end{array}$ & $\begin{array}{l}\frac{(\mathrm{a})}{(\mathrm{b})} \\
(\mathrm{f})\end{array}$ & $\begin{array}{l}\frac{(\mathrm{d})}{(\mathrm{c})} \\
(\mathrm{g})\end{array}$ \\
\hline $\begin{array}{l}\text { Glucose-6-phosphate } \\
\text { dehydrogenase }\end{array}$ & 0.429 & 0.622 & 0.506 & 0.391 & 1.2 & 0.7 & 0.8 \\
\hline $\begin{array}{l}\text { Glycerol } \\
\text { dehydrogenase }\end{array}$ & 0.410 & 0.458 & 0.367 & 0.367 & 1.3 & 0.9 & 1.0 \\
\hline $\begin{array}{l}\text { Lactate } \\
\quad \text { dehydrogenase }\end{array}$ & 0.195 & 0.079 & 0.148 & 0.160 & 0.5 & 2.5 & 1.1 \\
\hline $\begin{array}{l}\text { Alcohol } \\
\text { dehydrogenase }\end{array}$ & 0.017 & 0.040 & 0.068 & 0.041 & 0.6 & 0.4 & 0.6 \\
\hline $\begin{array}{l}\text { Formate } \\
\text { dehydrogenase }\end{array}$ & 1.215 & 1.490 & 0.044 & 0.556 & 33.9 & 0.8 & 12.7 \\
\hline $\begin{array}{l}\text { Pyruvate } \\
\text { decarboxylase }\end{array}$ & 0.320 & 0.729 & 0.390 & 0.370 & 1.9 & 0.4 & 1.0 \\
\hline Acetate kinase & 7.5 & 17.0 & 20.3 & 20.6 & 0.8 & 0.4 & 1.0 \\
\hline $\begin{array}{l}\text { Phosphate acetyl- } \\
\text { transferase }\end{array}$ & 28.5 & 41.0 & 55.4 & 47.5 & 0.7 & 0.7 & 0.9 \\
\hline Citrate synthase & 4.10 & 0.90 & 0.30 & 4.10 & 3.0 & 4. 6 & 13.7 \\
\hline Aconitate hydratase & 0.318 & 0.119 & 0.051 & 0.423 & 2.3 & 2.7 & 8.3 \\
\hline Isocitrate lyase & 0.064 & 0.008 & 0.007 & 0.109 & 1.1 & 8.0 & 15. 6 \\
\hline
\end{tabular}




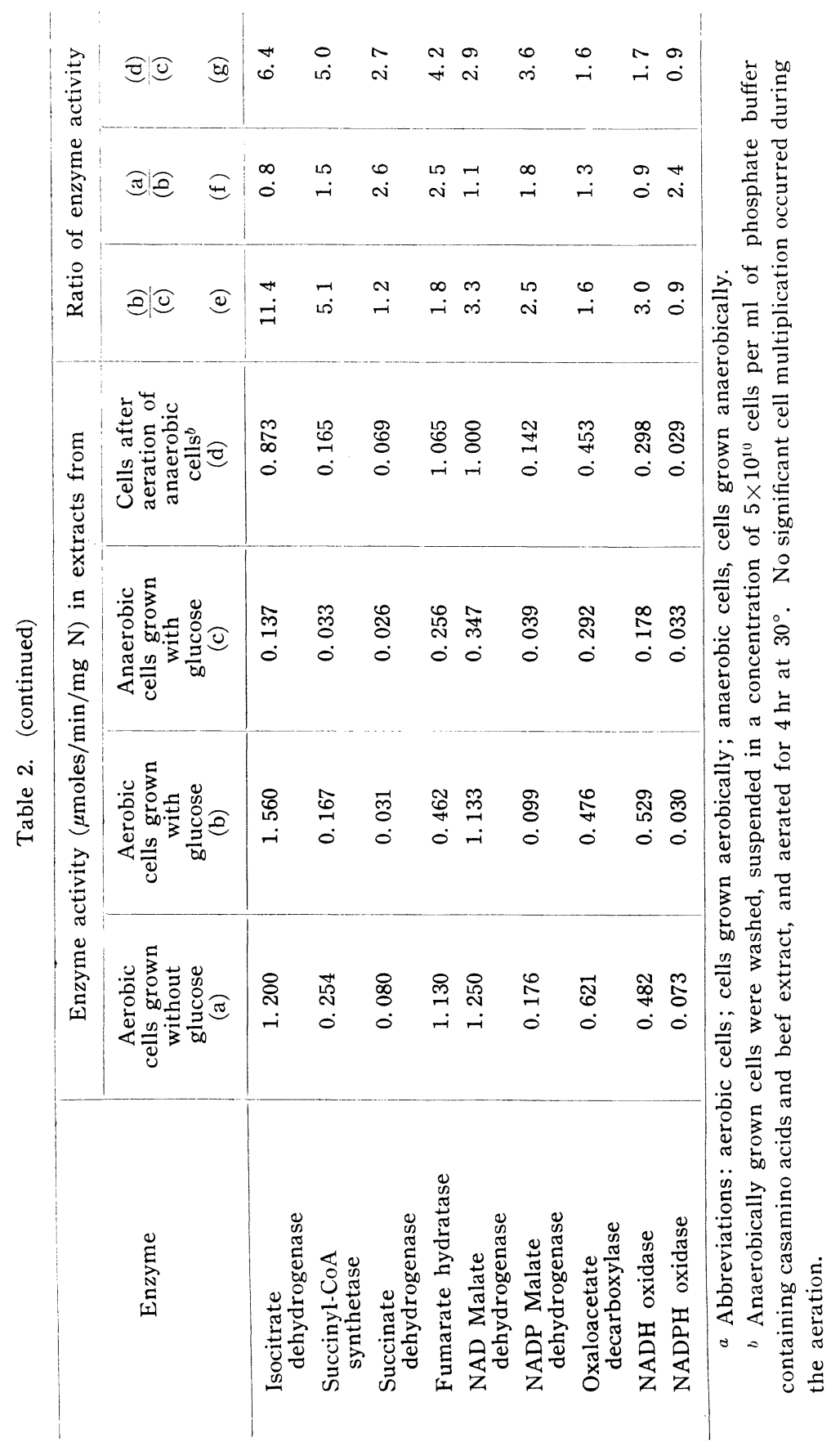


enzymes assayed in the present experiment.

Citrate synthase, aconitate hydratase, isocitrate lyase, and isocitrate dehydrogenase showed a marked increase by aeration of anaerobically grown cells, and the activity reached the level of cells grown aerobically in glucosefree media. The presence of glucose during aerobic culture was very toxic to the development of citrate synthase and isocitrate lyase, while the absence of oxygen markedly depressed the level of isocitrate dehydrogenase. A short lag (about 30 to $60 \mathrm{sec}$ ) was observed in the measurement of isocitrate lyase after the addition of the substrate, as reported by DIXON and KORNBERG (7).

The activity of succinyl-CoA synthetase, succinate dehydrogenase, fumarate hydratase, and NAD-malate dehydrogenase showed three-to fivefold activation by aeration of anaerobically grown cells; the activity reached the level of cells grown aerobically in glucose-free media. Glucose in aerobic cultures slightly repressed the level of succinate dehydrogenase and fumarate hydratase, while the absence of oxygen diminished the development of succinyl-CoA synthetase and NAD-malate dehydrogenase.

Aeration of anaerobically grown cells caused about four-fold increase in the activity of NADP-malate dehydrogenase and slight increase in the activity of oxaloacetate decarboxylase. There was a little effect of glucose on the cellular level of NADP-malate dehydrogenase.

The activity of NADH oxidase was different between cells grown aerobically and anaerobically, but the activity was not different between cells grown aerobically with and without glucose. The cells grown aerobically in glucose-free media were about twice as active in NADPH oxidase as cells grown aerobically or anaerobically in glucose-containing media. Aeration of anaerobically grown cells resulted in slight but definite increase in the activity of NADH oxidase but no increase in the activity of NADPH oxidase.

\section{DISCUSSION}

There is a considerable evidence $(21-27)$ that the formation of cytochromes in several bacteria is influenced by environmental growth conditions, particularly by oxygen tension and by the presence or absence of glucose. In $E$. coli, the content of cytochromes $\mathrm{a}_{1}, \mathrm{a}_{2}$ and $\mathrm{b}_{1}$ is reported to be lower in anaerobically than aerobically grown cells $(1,28-30)$, though the content is not significantly influenced by the presence of glucose ( 1 ).

In contrast to such extensive studies on cytochrome formation, reports concerning the environmental influence on the formation of the other respiratory enzymes are scarce in bacteria; Pasteurella pestis $(13,31)$, Aerobacter aerogenes (32), and $E$. coli $(29,33-35)$ are among the few that have so far been reported. Furthermore, with possible exception of $P$. pestis, the enzymes examined have been almost confined to the member of the tricarboxylic acid cycle. In the present study, about 20 enzymes were examined to obtain general picture for the effect of oxygen and glucose on the cellular constitution of 
fermentative and respiratory enzymes.

In the present study, anaerobically grown cells were cultured in media containing glucose to obtain sufficient cell yield. Since glucose is toxic to the development of respiratory activity in $E$. coli ( 1 ), anaerobically grown cells received dual effects, by anaerobiosis and by glucose, on their enzyme constitution. A comparison of enzyme activities between cells grown anaerobically with glucose and cells grown aerobically with glucose reveals the effect of oxygen, while a comparison between cells grown aerobically with and without glucose reveals the effect of glucose on the enzyme constitution.

The result of such a comparison shows (column (e) in Table 2) that aerobically grown cells are more than ten times as active as anaerobically grown cells in formate and isocitrate dehydrogenases, several times as active in succinyl-CoA synthetase, 2 to 3 times as active in citrate synthase, aconitate hydratase, fumarate hydratase, NAD- and NADP-dependent malate dehydrogenases, oxaloacetate decarboxylase, and NADH oxidase system. There was no significant difference in the activity of the remaining enzymes. These experimental results confirm the results in previous reports $(33,35)$, and further reveal that formate dehydrogenase, NADP-dependent malate dehydrogenase, and oxaloacetate decarboxylase are more active in aerobically than in anaerobically grown cells. These results also show that enzymes in fermentative pathway are little influenced by the presence or absence of oxygen.

As for the effect of glucose, the present results show (column ( $f$ ) in Table 2) that cells grown without glucose are several times more active than the cells grown with glucose in isocitrate lyase and citrate synthase, 2 to 3 times more active in aconitate hydratase, succinate dehydrogenase, fumarate hydratase, NADP-malate dehydrogenase, and NADPH oxidase system. The presence of glucose does not significantly influence the level of enzymes in fermentative pathways, nor formate dehydrogenase which is remarkably affected by oxygen.

HALPERN et al. (34) and GRAY et al. (33) examined the effect of glucose on the level of the tricarboxylic acid cycle enzymes in $E$. coli and reported that glucose-grown cells are deficient in these enzymes. The present results are compatible with their results in that glucose represses the level of some of the tricarboxylic acid cycle enzymes. Our results show, however, that the level of isocitrate dehydrogenase and succinyl-CoA synthetase is not influenced by glucose, though their level is distinctly influenced by oxygen. On the other hand, isocitrate lyase, which is little influenced by oxygen, is markedly repressed by glucose. It thus appears that oxygen profoundly influences the level of the tricarboxylic acid cycle enzymes, while glucose affects the level of the enzymes in glyoxylate cycle.

Previous studies about environmental influences on the level of cytochromes and other respiratory enzymes in bacteria have been limited to the comparison of activities between separately grown cells. In a series of studies $(1,2)$ on the development of respiratory activity in $E$. coli, we used 
resting cells to avoid possible selective growth of a certain type of cells and to minimize possible change in the composition of aeration mixture. These results indicated that respiratory activity increases by aeration of anaerobically grown cells in resting condition. As shown in the present study (column (g) in Table 2), activities of about 10 enzymes in anaerobically grown cells increased to the level of cells grown aerobically in the absence of glucose, by aeration for $4 \mathrm{hr}$ in a buffer containing casamino acids and beef extract, without accompanying notable cell multiplication. Since our previous results indicated that protein synthesis is involved in the development of respiration $(1,2)$, the present results strongly suggest that these enzymes are synthesized during the aeration. If the results of our previous study (2) are considered together, it may be concluded that the development of respiratory activity in anaerobically grown cells is caused by the increase of permeability to some of the respiratory substrates and by the increase in the content of the tricarboxylic acid cycle and glyoxylate cycle enzymes, but not by the increase of coenzyme content or by the disappearance of respiratory inhibitors.

It is well known that yeast cells grown anaerobically or cells grown aerobically in the presence of glucose are low in the level of several respiratory enzymes and that aeration of such cells in resting condition results in the increased activity of these enzymes. Our results with $E$. coli are apparently very similar to the results reported with yeast, but there is a striking difference between these two organisms. In yeast, profound influence of aeration was observed in enzymes of electron transport system, while in $E$. coli, the effect of aeration is remarkable in the TCA cycle enzymes but not in the enzymes in electron transport system, as is evident from the fact that there are only 2- to 3-fold increase in the content of cytochromes (1) and in the activity of $\mathrm{NADH}$ or $\mathrm{NADPH}$ oxidation, in contrast to nearly 10-fold increase in some of the tricarboxylic acid cycle enzymes. The difference between these two organisms probably reflects the fact that respiratory enzymes in yeast are located in mitochondria, while those in $E$. coli are not located in such organella.

This work was supported by a Grant-in-Aid for Scientific Research from the Ministry of Education.

\section{REFERENCES}

1) S. Hino and M. MaEdA, J. Gen. Appl. Microbiol., 12, 247 (1966).

2) Y. Takahashi and S. Hino, J. Gen. Appl. Microbiol., 14, 93 (1968).

3) R.D. DeMoss, In Methods in Enzymology, Vol. I, ed. by S.P. Colowick and N.O. Kaplan, Academic Press, Inc., New York (1955), p. 328.

4) R.M. Burton, In Methods in Enzymology, Vol. I, ed. by S.P. Colowick and N.O. KAPLAN, Academic Press, Inc., New York (1955), p. 397. 
5) E. Racker. In Methods in Enzymology, Vol. I, ed. by S.P. Colowick and N.O. Kaplan, Academic Press, Inc., New York (1955), p. 500.

6) E. Itagaki, T. Fujita and R. Sato, J. Biochem. (Tokyo), 52, 131 (1962).

7) G.H. Dixon and H.L. KornBerg, Biochem. J., 72, 3 P (1959).

8) A. Kornberg, In Methods in Enzymology, Vol. I, ed. by S.P. Colowick and N.O. Kaplan, Academic Press, Inc., New York (1955), p. 705.

9) E. RACKer, Biochim. Biophys. Acta, 4, 211 (1950).

10) O. ARrigoni and T.P. Singer, Nature, 193, 1256 (1962).

11) S. OchoA, In Methods in Enzymology, Vol. I, ed. by S.P. Colowick and N.O. Kaplan, Academic Press, Inc., New York (1955), p. 735.

12) D.E. Green and D.M. ZIEgler, In Methods in Enzymology, Vol. VI, ed. by S.P. Colowick and N.O. Kaplan, Academic Press, Inc., New York (1963), p. 416.

13) E. ENGLESBERg and J.B. Levy, J. Bacteriol., 69, 418 (1955).

14) I.A. Rose, In Methods in Enzymology, Vol. I, ed. by S.P. Colowick and N.O. Kaplan, Academic Press, Inc., New York (1955), p. 591.

15) F. Lipmann and L.C. Tuttle, J. Biol. Chem., 159, 21 (1945).

16) E.R. Stadtman, In Methods in Enzymology, Vol. I, ed. by S.P. Colowick and N.O. Kaplan, Academic Press, Inc., New York (1955), p. 596.

17) S. OгноA, In Methods in Enzymology, Vol. I, ed. by S.P. Colowick and N.O. Kaplan, Academic Press, Inc., New York (1955), p. 685.

18) G.D. Novelli and F. Lipmann, J. Biol. Chem., 182, 213 (1950).

19) S. Kaufman, In Methods in Enzymology, Vol. I, ed. by S.P. Colowick and N.O. Kaplan, Academic Press, Inc., New York (1955), p. 714.

20) D.H. Deutsch and R.E. Phillips, In Methods in Enzymology, Vol. III, ed. by S.P. Colowick and N.O. Kaplan, Academic Press, Inc., New York (1957), p. 421.

21) J. Lascelles, Tetrapyrrole Biosynthesis and its Regulation, W.A. Benjamin, Inc., New York and Amsterdam (1964).

22) E. Azoulay and P. Couchoud-Beaumont, Biochim. Biophys. Acta, 110, 301 (1965).

23) K. Tuzimura and I. Watanabe, Plant and Cell Physiol., 5, 157 (1964).

24 N.J. Jacobs, E.R. Maclosky and S.F. Cont, J. Bacteriol., 93, 278 (1967).

25) G.D. Clark-Walker, B. Rittenberg and J. Lascelles, J. Bacteriol., 94. 1648 (1967).

26) F.E. Frerman and D.C. White, J. Bacteriol., 94, 1868 (1967).

27) D.C. White, J. Bacteriol., 93, 567 (1967).

28) F. Moss, Austral. J. Exptl. Biol., 30, 531 (1952).

29) C.T. Gray, J.W.T. Wimpenny, D.E. Hughes and M.R. Mossman, Biochim. Biophys. Acta, 117, 22 (1966).

30) S. Hino, A. IshidA and Y. TAKAhashi, Abstracts, 7th International Congress of Biochemistry (Tokyo), p. 841 (1967).

31) E. Englesberg, J.B. Levy and A. Gibor, J. Bacteriol., 68, 178 (1954).

32) P. Forget and F. Pichinoty, Ann. Inst. Pasteur, 112, 261 (1967).

33) C.T. Gray, J.W.T. Wimpenny and M.R. Mossman, Biochim. Biophys. Acta, 117, 33 (1966).

34) Y.S. Halpern, A. Even-Shoshan and M. Artman, Biochim. Biophys. Acta, 93, 228 (1964).

35) S. Hino and Y. Takahashi, J. Japan Biochem. Soc., 37, 671 (1965). 